\title{
EHMTI-0200. Aerobic exercise training at the ventilatory threshold prevents migraine and improves mood
}

\author{
AB Oliveira ${ }^{* *}$, RT Ribeiro ${ }^{1}$, MT Mello², S Tufik ${ }^{2}$, MFP Peres $^{1}$ \\ From 4th European Headache and Migraine Trust International Congress: EHMTIC 2014 \\ Copenhagen, Denmark. 18-21 September 2014
}

\section{Introduction}

The ventilatory threshold (VT) is a standardized, individual parameter of metabolic demand during exercise. No study on the preventive effect of aerobic exercise training $(\mathrm{AE})$ for migraine $(\mathrm{M})$ has used the VT.

\section{Aims}

To measure changes in M clinical outcomes and mood state after a standardized AE program.

\section{Methods}

The study recruited episodic $M$ patients with and without aura (ICHDII) taking no preventive medicine. Study protocol comprised 12-week of AE, performed 3 times/wk, 30 $\mathrm{min}$./session at the VT. Participants were randomly allocated for AE (EXE) or waiting list (CT) groups. VT was determined by a computerized open-circuit gas analyser during maximal cardiopulmonary exercise test for assessment of aerobic fitness (VO2max). The corresponding heart rate, workload, and perceived effort at VT were used to monitor AE intensity. Days with M (Days), M frequency (FREQ), disability (DIS), medication (MED), depression (BECKII), anxiety (GAD7) and mood (POMS) were measured at baseline and after AE.

\section{Results}

25 patients (EXE, $\mathrm{N}=13 ; \mathrm{CT}, \mathrm{N}=12$ ) completed the study. All participants' characteristics and baseline measurements matched between groups. CT changed no post-intervention variable. For EXE, there were reduction in DAYS $(8.9 \pm 3.6$ vs $5.6 \pm 3.4, \mathrm{p}=0.002)$, FREQ $(6.3 \pm 3.0$ vs $3.8 \pm 2.4, \mathrm{p}=0.002)$, POMS $(27.3 \pm 35.1$ vs $6.7 \pm 13.1$,

${ }^{1}$ Neurologia and Neurocirurgia, Universidade Federal de São Paulo, São Paulo, Brazil

Full list of author information is available at the end of the article $\mathrm{p}=0.038)$, GAD7 $(7.2 \pm 5.1$ vs $4.2 \pm 3.3, \mathrm{p}=0.034)$, and $\mathrm{a}$ trend to decrease in BECKII $(6.3 \pm 3.0$ vs $3.8 \pm 2.4$, $\mathrm{p}=0.067)$, and increase in $\mathrm{VO} 2 \max (30.8 \pm 6.5$ vs $32.1 \pm 5.5$, $\mathrm{p}=0.049)$ after AE.

\section{Conclusions}

Metabolic-matched AE using VT prevented M and improved mood.

No conflict of interest.

\section{Authors' details}

${ }^{1}$ Neurologia and Neurocirurgia, Universidade Federal de São Paulo, São Paulo, Brazil. 'Psicobiologia, Universidade Federal de São Paulo, São Paulo, Brazil.

Published: 18 September 2014

doi:10.1186/1129-2377-15-S1-D45

Cite this article as: Oliveira et al:: EHMTI-0200. Aerobic exercise training at the ventilatory threshold prevents migraine and improves mood. The Journal of Headache and Pain 2014 15(Suppl 1):D45.

Submit your manuscript to a SpringerOpen ${ }^{\odot}$ journal and benefit from:

- Convenient online submission

- Rigorous peer review

- Immediate publication on acceptance

- Open access: articles freely available online

- High visibility within the field

Retaining the copyright to your article

Submit your next manuscript at $>$ springeropen.com

\section{SpringerOpen $^{\odot}$}

C 2014 Oliveira et al; licensee Springer. This is an Open Access article distributed under the terms of the Creative Commons Attribution License (http://creativecommons.org/licenses/by/2.0), which permits unrestricted use, distribution, and reproduction in any medium, provided the original work is properly cited. 